\title{
The relation between serum lipids and lutein and zeaxanthin in the serum and retina: results from cross-sectional, case-control and case study designs
}

\author{
Lisa M Renzi ${ }^{1 *}$, Billy R Hammond $\mathrm{Jr}^{2}$, Melissa Dengler ${ }^{3}$ and Richard Roberts ${ }^{4}$
}

\begin{abstract}
Background: The xanthophyll carotenoids lutein $(L)$ and zeaxanthin $(Z)$ are found in and around the macula of the primate retina, where they are termed macular pigment (MP). Dietary $L$ and $Z$ are absorbed with fat in the gut and transported on lipoproteins to the retina. Both MP and serum lipoproteins have been related to risk for neurodegenerative diseases such as age-related macular degeneration (AMD). $L$ and $Z$ are carried on both $\mathrm{HDL}$ (related to reduced risk of AMD) and LDL (related to increased risk). The purpose of this set of studies was to analyze the relation between $L$ and $Z$ in the serum and retina with the circulating lipid profile.

Methods: In all experiments, lipoproteins were measured enzymatically from plasma, and MP optical density (MPOD) was measured using customized heterochromatic flicker photometry. Experiment 1: Relations between serum $L$ and $Z, M P O D$ and lipoprotein levels. 108 young, healthy subjects $(M=23.2, S D=4.12$ years) participated. Lipoprotein levels and MPOD were measured. In a subset of 66 participants, serum $L$ and $Z$ levels were also measured using high-performance liquid chromatography. Experiment 2: Relations between lipoprotein levels and MPOD in statin users. 20 subjects $(M=58.05, S D=11.08$ years) taking statin medication and 20 subjects $(M=57.95$, $S D=11.03$ years) not taking satin were recruited for participation. MPOD and lipoprotein levels were measured. Experiment 3: lowering lipoprotein levels to impact MPOD. One individual (aged 41 years) with high MP density adhered first to an atorvastatin regimen, then, after a wash-out period, to a rosuvastatin regimen.

Results: Experiment 1: HDL were significantly $(p<0.05)$ related to MPOD $(r=0.33)$, to serum $L(r=0.36)$ and to serum Z $(r=0.26)$. MPOD was also significantly related to total cholesterol $(r=0.19)$. Experiment 2: MPOD was not lower in statin users when compared to matched non-statin users, but MPOD decreased significantly with increased duration of statin use $(r=-0.63)$. Experiment 3: Administration of a statin regimen reduced MPOD with atorvastatin $(p<0.05)$ but not with rosuvastatin.

Conclusions: Serum xanthophylls, retinal xanthophylls and lipoprotein concentrations are significantly related, and changing lipoprotein levels may impact levels of retinal xanthophylls.
\end{abstract}

Keywords: Macular pigment, Lipoproteins, Statins, Lutein, Zeaxanthin

\section{Background}

Approximately 600-800 different carotenoids exist [1,2] and serve a multitude of functions such as light harvesting for plant photosynthesis and protection from free-radical damage (for review, see [1-3]). Carotenoids cannot be synthesized by the majority of animal species de novo and

\footnotetext{
* Correspondence: Irenzi@uga.edu

'Human Biofactors Laboratory and Vision Sciences Laboratory, The University of Georgia, 601 Psychology Building, Athens, GA 30602-3013, USA

Full list of author information is available at the end of the article
}

must, consequently, be consumed in the diet. Of the 600800 carotenoids that have already been classified in nature, only a small number (about 25) is found in commonlyconsumed foods [4] and, therefore, human serum. Carotenoids in the body retain many of their original plant functions, such as light absorption in the eye and in skin, and singlet oxygen quenching in a variety of tissues. Carotenoids can also improve cell membrane stability, alter transcriptional activity, regulate immune function, reduce

\section{C) Biomed Central}


inflammation and even, possibly, improve neural functioning (e.g., [2,3,5-10]).

The majority of somatic tissues contain carotenoids, and the majority of these tissues contain more than one carotenoid. There are, however, some tissues that tend to absorb one or two carotenoids to the exclusion of others. For example, lutein $(\mathrm{L})$ and zeaxanthin $(\mathrm{Z})$ are found alongside a number of other carotenoids (e.g., alpha-carotene, beta-carotene, beta-cryptoxanthin, lycopene) in tissues such as liver, kidney and lung (e.g., [11]) but are the only carotenoids found in the crystalline lens $[12,13]$ and macular region of the neural retina, where they and their isomer meso-zeaxanthin (MZ) are termed macular pigment (MP) (e.g., [14,15]). In the macula, $\mathrm{L}$ and $\mathrm{Z}$ are thought to serve many of the above functions, and high MP optical density (MPOD) has been linked to reduced risk of age-related macular degeneration (AMD), an acquired neurodegenerative disease and one of the world's leading causes of blindness [16-20]. AMD has similar risk profiles to other neurodegenerative diseases, such as Alzheimer's disease (e.g., [21-23]), and to cardiovascular disease ([24-29]. Among those risk factors are high plasma concentrations of low-density lipoproteins (LDL) (e.g., [28,30-33], low concentrations of high-density lipoproteins (HDL) (e.g., $[30,31,34,35])$, elevated plasma triglyceride concentrations (e.g., $[29,30,32]$ ), and low serum $L$ and $Z$ levels (e.g., [36-42])

Dietary $\mathrm{L}$ and $\mathrm{Z}$ are absorbed with fats in the gut and are eventually transported to the liver (e.g., [43]). L and Z within the liver are incorporated into lipoprotein molecules that are transported throughout the bloodstream as part of a carotenoid-lipoprotein complex. The association of individual carotenoids with the various lipid fractions is relatively specific and is determined by the size and hydrophilicity of the carotenoid. For example, pure hydrocarbon carotenoids like beta-carotene and lycopene are carried predominately on LDL fractions, which is largely the basis for the suggestion that they may play a preferential role in reducing LDL oxidation [44]. Other carotenoids, such as the more hydrophilic xanthophylls, show different patterns of transport. L, for example, is carried preferentially on HDL (approx. 52\%) and to a lesser extent on LDL (22\%) [45]. Past data has shown that circulating levels of $\mathrm{L}$ and $\mathrm{Z}$ are positively correlated with both serum HDL and LDL fractions but not with VLDL fractions [46].

Given the fact that carotenoids are bound to circulating lipoproteins (and delivered to target tissues via this mechanism), the relation between serum levels of the various lipoprotein and tissue concentrations of carotenoids is of interest. Unlike other carotenoids, retinal $\mathrm{L}$ and $\mathrm{Z}$ (i.e., MP) can be measured in situ and non-invasively using psychophysical methods, such as heterochromatic flicker photometry (HFP) (e.g., [47]). Consequently, it is relatively easy to measure relationships between circulating lipoproteins, serum L and Z levels and MP density. Given the fact that concentrations of both the carotenoid and the lipoprotein carrier are related to risk for AMD (e. g., $[16,26,30,31,39])$, Alzheimer's disease (e.g., [36,37]) and cardiovascular disease (e.g., $[24-28,38,48]$ ), it would be useful to determine whether or not these sources of risk are independent. For example, the question of whether HMG Co-A reductase inhibitors (i.e., statins), increasingly widely used, and which are known to reduce circulating lipoprotein levels, impact the amount of $\mathrm{L}$ and $\mathrm{Z}$ available to bind to brain and retina has not been studied.

Past research that has addressed the relations between plasma lipoproteins, serum $\mathrm{L}$ and $\mathrm{Z}$ and MPOD has been conflicting and has largely not addressed the issue of statin use. For example, Broekmans et al [49] originally measured MP using a reflectance method and related those measures to serum carotenoids and plasma lipoprotein concentrations in 376 subjects. Like past studies, they found a positive relation between serum $L$ and plasma HDL and LDL fractions. They also found a negative relation between MP and serum triglycerides but no relation between MPOD and HDL and LDL. These results are interesting but difficult to interpret. For instance, Broekmans et al [49] reported an average serum $\mathrm{L}$ and $\mathrm{Z}$ level of about $0.23 \mu \mathrm{mol} / \mathrm{L}$, which is $44 \%$ lower than the average normative value reported by the large sample $(\mathrm{n}=7059)$ studied in the Third National Health and Nutrition Examination Survey (NHANES III) (0.41 $\mu \mathrm{mol} / \mathrm{L}$ ) [50]. Broekmans and colleagues also report lipid profiles that contrast with NHANES III norms (e.g., 23\% higher triglyceride levels compared to levels reported by the National Cholesterol Education Program) [51] (16). Approximately $32 \%$ of the sample were smokers and, unlike other studies [52,53], MP density was not related to smoking status in their sample. Taken together, the sample and results reported by Broekmans et al. appear to be different enough that their data probably should not be regarded as sufficiently representative to make their results conclusive.

More recently, Loane et al [54] investigated the relationship between serum $\mathrm{L}$ and $\mathrm{Z}$, plasma lipoproteins and MPOD. In contrast to Broekmans et al [49], Loane and colleagues found that serum $\mathrm{L}$ and $\mathrm{Z}$ concentrations were positively related to total cholesterol and HDL, and inversely related to plasma triglyceride concentrations, but not to LDL. No relationships, positive or inverse, were seen between any of the lipoproteins tested and MPOD. Given the conflicting nature of past research in this area, we present a collection of three separate studies, conducted at different times with different samples, that is designed to clarify the relationship between plasma lipoprotein levels, serum $\mathrm{L}$ and $\mathrm{Z}$ and MPOD in 
participants varying widely in MPOD and lipoprotein levels (including statin users) across the lifespan.

\section{Methods \\ General}

Although each of these experiments was conducted at a different time point, each experiment was approved by the University of Georgia Institutional Review Board, and the tenets of the Declaration of Helsinki were adhered to at all times. All values below are expressed as mean \pm standard deviation.

\section{Participants}

Experiemnt 1: Relations between serum $L$ and $Z, M P O D$ and lipoprotein levels

108 young, healthy subjects ( 44 males, 64 females; $M=$ $23.20 \pm 4.12$ years) were recruited from the University of Georgia student research participant pool as part of a larger, ongoing study on the effects of lutein supplementation on visual function. Informed consent was issued and all practices and procedures were approved by the University of Georgia Institutional Review Board. All participants were free of ocular disease, had best corrected visual acuity of at least 20:40 or better (Snellen notation), and reported no history of ocular disease. Participants were given a medical examination by a qualified physician prior to enrollment to ensure general good health.

\section{Experiment 2: Relations between lipoprotein levels and $M P O D$ in statin users}

A total of 20 individuals who had been taking statin medication for a period of at least four-months prior to enrollment were recruited from the Athens, GA community. These participants ( $\mathrm{n}=13$ males, 7 females, $M$ $=58.05 \pm 11.08$ years) were carefully matched with 20 healthy individuals not on statins $(\mathrm{n}=14$ males, 6 females, $M=57.95 \pm 11.03$ years) on a number of factors known to influence MPOD, such as BMI, smoking status, presence of Type II diabetes and carotenoid intake. Prospective participants were screened by questionnaire and excluded on the basis of the following parameters: known diagnosis of HIV, use of blood-thinning medications, confirmed diagnosis of sarcoma or carcinoma within the last 5 years, use of chemotherapy and immunosuppressive medications, visual acuity that could not be corrected to $20 / 60$ or better, and failure to meet fasting requirements of 12 hours or more prior to participation.

\section{Experiment 3: case-study: lowering lipoprotein levels to impact MPOD}

One mildly hyperlipidemic (total cholesterol $=6.18$ $\mathrm{mmol} / \mathrm{L}, \mathrm{LDL}=4.15 \mathrm{mmol} / \mathrm{L}$ ) subject (male, 41 years of age) who was experienced in the psychophysical methodology used in this study (described below) underwent a low-dose $(10 \mathrm{mg})$ atorvastatin (Lipitor ${ }^{\circledR}$, Pfizer Pharmaceuticals) intervention for one-month. The subject otherwise met inclusion criteria listed for Experiment 2 above and maintained stable dietary and exercise habits during the course of the study. Following a two-year wash out period, the same subject began a one-month regimen $(10 \mathrm{mg})$ of rosuvastatin $\left(\right.$ Crestor $^{\circledR}$, AstraZenca Pharmaceuticals). Although statin medications lower cholesterol production via inhibition of HMG-CoA reductase in the liver, lipophilic atorvastatin is, like its counterparts simvastatin and lovastatin, known to cross the blood-brain barrier, unlike hydrophilic rosuvastatin and its counterparts fluvastatin and pravastatin [55]. Both lipophilic and hydrophilic statins were used to ensure that any resulting changes in MP density were due to lipid-lowering activities as opposed to any direct neural influence of statins that cross the blood-brain barrier or, by extension, the blood-retina barrier.

\section{Materials and methods}

Plasma lipoprotein concentrations

\section{Experiment 1}

Lipids were analyzed from the plasma samples scheduled for xanthophyll quantitation. LDL, HDL, cholesterol and triglyceride levels were measured in heparinized plasma using commercially available test kits on a Roche-Hitachi Clinical Autoanalyzer. In brief, for LDL and HDL analysis, the respectively bound cholesterol is enzymatically cleaved and oxidized. This oxidation leads to hydrogen peroxide as side-product, which is quantified using a color reaction. For analysis of triglycerides, glycerol is enzymatically freed using lipases, followed by an oxidation leading to hydrogen peroxide as side-product. This is quantified using a color reaction and measured with photometry.

\section{Experiments 2 and 3}

In order to make lipoprotein analysis more convenient for older adults and for repeated testing on the case study, plasma total cholesterol, HDL, LDL and triglyceride levels were assessed via the Cholestech LDX portable lipid analyzer (Cholestech Corporation). Portable lipid analyzers provide a reasonably accurate and convenient way to screen participants for lipid status [56,57]. The LDX is able to accurately measure lipid profiles when samples are derived from whole blood, when a single, trained operator performs lipid analysis, and when all precautions are taken to avoid error during the collection phase (e.g., swabbing the finger with alcohol, collecting while fingertips are warm, not 'milking' the finger, etc.) [57]. Consequently, all whole blood samples were collected under these conditions. To ensure proper functioning of the LDX system, quality control was performed periodically utilizing known internal standards (Cholestech Corporation). 


\section{Serum $L$ and $Z$ (Experiment 1 only)}

Participants in Experiment 1 were, as stated previously, recruited for a larger, ongoing study on lutein supplementation and visual function. Serum was analyzed for $\mathrm{L}$ and $\mathrm{Z}$ concentration in 66 of those 108 initially recruited participants during phase I of the larger study. For those 66 participants, L and Z levels were determined via high performance liquid chromatography (HPLC), as described previously [58]. Briefly, L and Z were extracted from the aqueous suspension with $n$ hexane/chloroform. After centrifugation, an aliquot of the organic phase was evaporated to dryness, re-dissolved in mobile phase and analyzed on a normal-phase (Si-60) HPLC system. The detection is performed with a $\mathrm{UV} / \mathrm{Vis}$ detector at $452 \mathrm{~nm}$ for both xanthophylls. The method is a standard one, which is regularly checked for accuracy and precision by attending to inter-laboratory studies organized by the National Institute of Standard \& Technologies (NIST) in the USA, and by the Societé Francophone Vitamine \& Biofacteurs (SFVB) in the European Union. To assess the daily and long-term laboratory performance of the HPLC plasma analytics, dedicated control plasma is used. The control samples are analyzed at least 4 times/day during the study.

\section{Dietary assessment (Experiment 2 only)}

Fruit and vegetable intake was measured via the commercially available 7-Item Eating Habits Screener ${ }^{\odot}$ from Block Dietary Data Systems. Burke et al [59] compared the 7-Item Eating Habits Screener ${ }^{\odot}$ with the more commonly used Fred Hutchinson Cancer Research Center Food Frequency Questionnaire (FFQ) and found that both screeners compared well in their ability to categorize dietary intakes of fruits and vegetables, including $\mathrm{L}$ and Z-rich fruits and vegetables, into low, medium, high and very high levels. Scores on both eating habits assessments were also significantly correlated with MPOD, tested at a central retinal locus $(r=0.24, p=0.02, \mathrm{n}=$ 96 with the Fred Hutchinson FFQ; $r=0.27, p=0.006$, n $=96$ with the 7-Item Eating Habits Screener ${ }^{\odot}$ ).

\section{MPOD measurement (all experiments)}

MPOD was measured psychophysically via customized HFP (cHFP). The method for assessing MPOD via cHFP has been previously described $[47,60]$. Briefly, the basic measurement procedure involves presenting a small test stimulus that alternates between a measuring wavelength strongly absorbed by MP $(460 \mathrm{~nm})$ and a reference wavelength not absorbed by the pigments (550 $\mathrm{nm})$. This stimulus is presented in the center of the fovea and at an eccentric location (7 degrees), which is used as a reference. In effect, the subject perceives a test light that appears to flicker. The subject is then instructed to adjust the intensity of the measuring light until flicker is eliminated. The log difference in the measurement and reference values yields a measure of MP optical density at the test locus. HFP is one of the most widely used and highly validated psychophysical techniques for assessing MP density (e.g., [61]). The denotation of "customized" HFP refers to an ability to optimize viewing conditions (e.g., low-frequency flicker rates) for each subject and has been validated in a wide variety of subjects.

\section{Results}

All statistics were computed utilizing Microcal Origin, version 8.1, and SPSS, version $18.0(p \leq 0.05$ defined significance).

\section{Experiment 1. Relations between serum $\mathrm{L}$ and $\mathrm{Z}$, MPOD and lipoprotein levels}

Descriptive statistics for all of the major dependent measures are shown in Table 1. A Pearson productmoment correlation matrix was constructed to describe the relation between lipoproteins, serum $\mathrm{L}$ and $\mathrm{Z}$, MPOD and BMI (see Table 2). As shown in the table, MP was positively related to HDL $(r=0.33, p<0.01)$ and total cholesterol $(r=0.19, p<0.05)$. MP did not significantly relate to any of the other lipoproteins, or to BMI. Serum L was marginally related to total cholesterol $(r=0.21, p<0.09)$ and was significantly related to HDL $(r=0.36, p<0.01)$. Serum $\mathrm{Z}$ was not related to total cholesterol but was significantly related to HDL ( $r=$ $0.26, p<0.05)$. These analyses controlled for age and sex.

\section{Experiment 2. Relations between lipoprotein levels and MPOD in statin users}

In order to determine whether statin-users and nonusers were well-matched, a one-way ANOVA was conducted on all matching parameters that were on the interval or ratio scales of measurement (see Table 3). No significant differences were seen between statinusers and non-users $(p \geq 0.05)$, indicating that the matching procedure was successful. To determine that lipid status was different between statin-users and nonusers, a series of independent samples $t$-tests were performed, using the Bonferroni procedure to control for family-wise error. Non-users showed significantly higher total cholesterol $(t=-3.09, p \leq 0.05)$, LDL cholesterol $(t$ $=-3.37, p \leq 0.05)$ and LDL:HDL ratios $(t=-2.05, p \leq$ $0.05)$ compared with statin-users. Consequently, we can state with some confidence that serum lipid status differed between the two groups, but other potentially confounding factors (e.g., BMI, smoking status, presence of Type II diabetes) were similar.

A comparison of MP density between statin-users and non-users showed that MP density was not significantly 
Table 1 Descriptive statistics for participants enrolled in Experiment 1 ( $n=108)$

\begin{tabular}{llllll}
\hline Variable & Mean & Standard Deviation & Range & Minimum Value & MaximumValue \\
\hline Age (years) & 23.22 & 4.11 & 23.00 & 18.00 & 41.00 \\
\hline BMI & 23.20 & 2.67 & 13.10 & 19.50 & 32.60 \\
\hline 30 -minute MPOD & 0.44 & 0.17 & 0.89 & 0.02 & 0.91 \\
\hline Total cholesterol $(\mathrm{mmol} / \mathrm{L})$ & 4.42 & 1.01 & 5.52 & 2.77 & 8.29 \\
\hline $\mathrm{HDL}(\mathrm{mmol} / \mathrm{L})$ & 1.47 & 0.38 & 2.05 & 0.70 & 2.75 \\
\hline Triglycerides $(\mathrm{mmol} / \mathrm{L})$ & 1.17 & 0.68 & 4.51 & 0.36 & 4.87 \\
\hline LDL $(\mathrm{mmol} / \mathrm{L})$ & 2.43 & 0.80 & 4.25 & 0.98 & 5.23 \\
\hline Lutein $(\mu \mathrm{mol} / \mathrm{L})$ & 0.19 & 0.10 & 0.44 & 0.05 & 0.49 \\
\hline Zeaxanthin $(\mu \mathrm{mol} / \mathrm{L})$ & 0.07 & 0.03 & 0.17 & 0.01 & 0.18 \\
\hline
\end{tabular}

different at any eccentricity along the spatial profile $(p \geq$ 0.05). After excluding individuals with Type II diabetes from the analysis, MP density was still not significantly different between statin users and non-users $(p \geq 0.05)$. However, a significant inverse correlation between duration of statin use and MP was found at all eccentricities tested $(r=-0.613, r=-0.442, r=-0.499, r=-0.685$ for 10-minutes, 15-minutes, one-degree and twodegrees, respectively) ( $p \leq 0.05)$, after controlling for age and presence of type II diabetes. An example of one of these relations is shown in Figure 1.

\section{Experiment 3. Case-study: lowering lipoprotein levels to} impact MPOD

Baseline, intervention and post-supplementation averages for the case study participant during both the atorvastatin intervention and the rosuvastatin intervention are shown in Table 4. Differences between MP density and serum lipids were assessed via one-way ANOVA with correction via the Bonferroni procedure to control for multiple comparisons. During the atorvastatin intervention, total cholesterol and LDL cholesterol dropped significantly from baseline $(p \leq 0.01)$ and remained low post-intervention $(p \leq 0.05)$. In addition, TC:HDL and LDL:HDL ratios were significantly lower during the atorvastatin intervention and post-intervention compared with baseline $(p \leq 0.05)$. MP density decreased significantly at the most peripheral locus (1.75-degrees) by about $60 \%$ during the intervention ( $p$ $\leq 0.05$ ). MP density rebounded to original levels postintervention. MP density decreased slightly but not significantly at other loci in the spatial profile during the intervention (See Table 4, Figure 2).

During the rosuvastatin intervention, total cholesterol was significantly lower during the intervention when compared with pre- and post-intervention periods ( $p \leq$ 0.05). Specific lipid fractions (i.e., HDL and LDL), did not differ significantly when compared independently of the total cholesterol value $(p \geq 0.05)$. MP density did not change significantly during the rosuvastatin intervention (See Table 4, Figure 3).

\section{Discussion}

The results of Experiment 1 suggest that MP is related to HDL but not the other lipoprotein fractions. This result is inconsistent with results from both Loane et al [54], who report no relation between MPOD and lipoproteins, and Broekmans et al [49], who report a significant difference between plasma triglycerides and MP. There are some noteworthy differences between these

Table 2 Pearson-product moment correlation coefficients between the dependent measures in Experiment 1 (n = 108)

\begin{tabular}{lllllllll}
\hline & MPOD & Body Mass Index & Total Cholesterol & HDL & LDL & Triglycerides & Serum L & Serum Z \\
\hline MPOD & $\mathbf{1}$ & -0.10 & $0.19^{*}$ & $-0.33^{* *}$ & 0.11 & -0.14 & $0.31^{*}$ & $0.21+$ \\
\hline Body Mass Index & $\mathbf{1}$ & -0.05 & -0.00 & -0.04 & -0.04 & -0.07 & -0.02 \\
\hline Total Cholesterol & & $\mathbf{1}$ & $0.42^{* *}$ & $0.90^{* *}$ & $0.41^{* *}$ & $0.21 \dagger$ & 0.05 \\
\hline HDL & & & $\mathbf{1}$ & 0.12 & $-0.20^{*}$ & $0.36^{* *}$ & $0.26^{*}$ \\
\hline LDL & & & & 1 & $0.29^{* *}$ & 0.10 & -0.03 \\
\hline Triglycerides & & & & & & -0.01 & -0.12 \\
\hline Serum L & & & & & & & \\
\hline Serum Z & & & & & & & $\mathbf{1}$ \\
\hline
\end{tabular}

Note: MPOD assessed at 30-min of eccentricity

${ }^{* *}=p \leq 0.01$, two-tailed

* $=p \leq 0.05$, two-tailed

$\dagger=p \leq 0.09$, two-tailed 
Table 3 Matching parameters for Experiment $2(n=40)$.

\begin{tabular}{|c|c|c|c|c|c|c|c|}
\hline Group & Age (years) & Gender & Iris Color* & BMI $\left(\mathrm{kg} / \mathrm{m}^{2}\right)$ & Carotenoid Intake Score & Smoking Status & Years Smoking \\
\hline $\begin{array}{l}\text { Statin } \\
\text { Users }\end{array}$ & $58.05 \pm 11.08$ & $\begin{array}{l}\mathrm{n}=13 \text { males } \\
\mathrm{n}=7 \text { females }\end{array}$ & $2.1 \pm 0.9$ & $27.51 \pm 5.19$ & $14.1 \pm 5.25$ & $\begin{array}{l}\mathrm{n}=13 \text { nonsmokers } \\
\mathrm{n}=7 \text { past smokers } \\
\mathrm{n}=0 \text { current smokers }\end{array}$ & $5.3 \pm 9.18$ \\
\hline Non-Users & $57.95 \pm 11.03$ & $\begin{array}{l}n=14 \text { males } \\
n=6 \text { females }\end{array}$ & $1.9 \pm 0.8$ & $26.34 \pm 2.73$ & $13.93 \pm 3.63$ & $\begin{array}{l}\mathrm{n}=12 \text { nonsmokers } \\
\mathrm{n}=4 \text { past smokers } \\
\mathrm{n}=4 \text { current smokers }\end{array}$ & $9.10 \pm 12.47$ \\
\hline
\end{tabular}

Values expressed as mean \pm SD unless otherwise indicated

*1 = dark irides, 2 = green/hazel irides, 3 = blue/gray irides

studies that may account for inconsistencies in results. For example, Broekmans and colleagues tested a larger number of subjects $(\mathrm{n}=376)$, and the relation they report is quite small $\left(r^{2}=0.03\right)$. The magnitude of the relationship in our study was similar but the sample was smaller and therefore there was not enough statistical power to reach significance. Also, we screened our sample for conditions that could affect L absorption (e.g., smoking and medical history). Broekmans et al also used different methods to test MP density that could have created a restricted range in their MP data (for review of methodological concerns for MP measurement, see [61]). Hence, it is likely that the differences in study population and methodology account for the differences between our results and those of Broekmans et al. Our results suggest that there is a significant and positive association between serum $\mathrm{L}$ and $\mathrm{Z}, \mathrm{MP}$ and HDL. This finding is consistent with a presumed mechanism of $\mathrm{L}$ and $\mathrm{Z}$ delivery to the retina. $\mathrm{L}$ and $\mathrm{Z}$ associate more closely with HDL and Thomson et al. (2002)[62] have suggested that a small proportion (2.5\%) of HDL might be responsible for transporting $\mathrm{L}$ and $\mathrm{Z}$ to the retina (with little or no role for the other lipids). Additional evidence for HDL as the major carrier for $\mathrm{L}$ has been provided by Connor et al [63], using WHAM chicks, which are HDL deficient.

The relation between MP and lipid-lowering medications appears to be less straightforward. For example, MP density was not significantly different between statin-users and non-users, despite the fact that lipid levels were higher

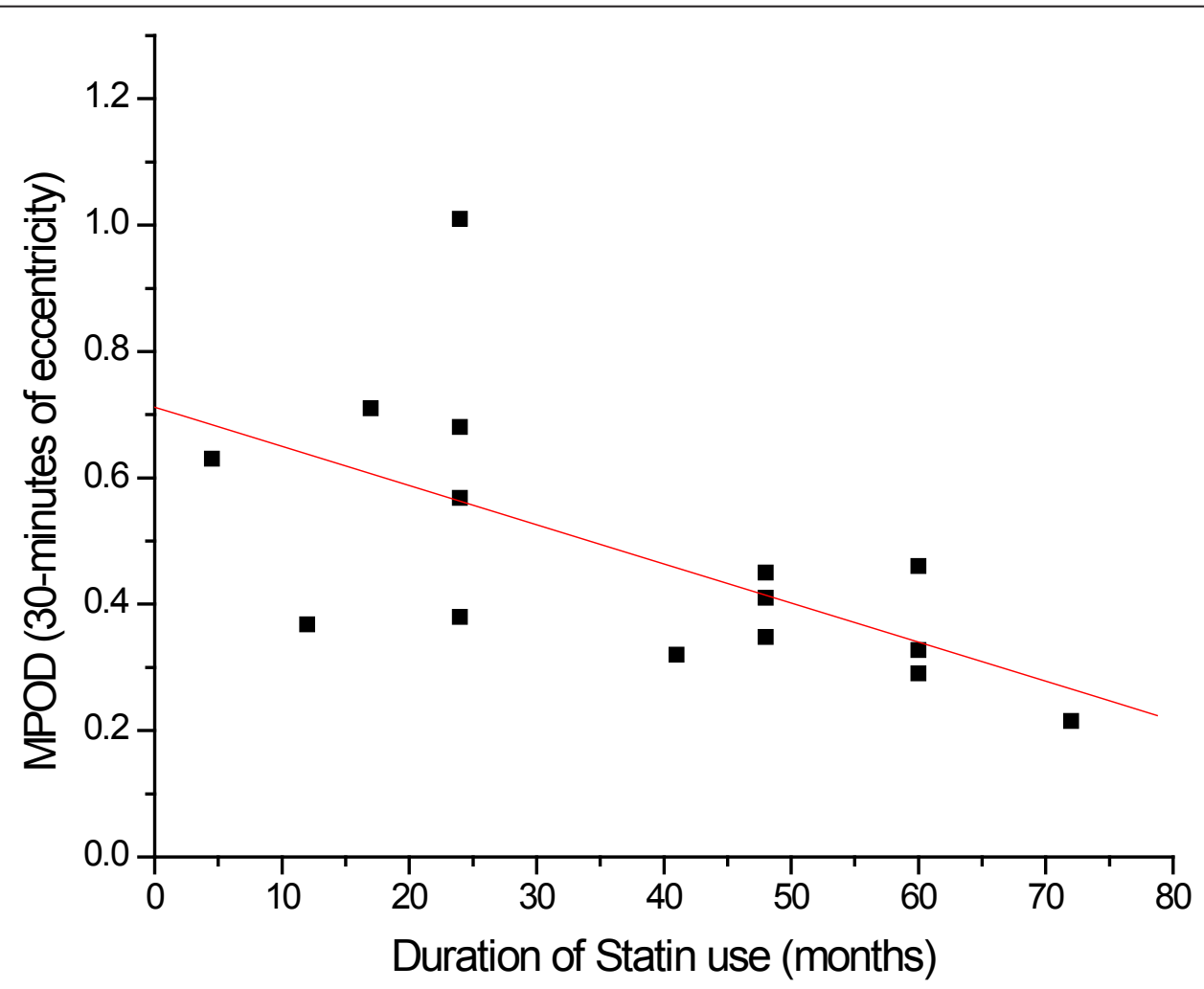

Figure 1 Decline in MPOD with increased duration of Statin use for participants in Experiment 2; $r=-0.613, p \leq 0.05$. Note that all 20 subjects are represented on the graph, but some points overlap. 
Table 4 Baseline, intervention and post-intervention lipid concentrations and MP densities for case study participant

\begin{tabular}{|c|c|c|c|c|c|c|c|c|c|}
\hline Phase & $\begin{array}{l}\text { 15-min MP } \\
\text { density }\end{array}$ & $\begin{array}{l}\text { 30-min MP } \\
\text { density }\end{array}$ & $\begin{array}{l}\text { 1-deg MP } \\
\text { density }\end{array}$ & $\begin{array}{l}\text { 1.75-deg MP } \\
\text { density }\end{array}$ & $\begin{array}{l}\text { TC } \\
\text { (mmol/ } \\
\text { L) }\end{array}$ & $\begin{array}{l}\mathrm{HDL} \\
(\mathrm{mmol} / \mathrm{L})\end{array}$ & $\begin{array}{l}\text { LDL } \\
(\mathrm{mmol} / \mathrm{L})\end{array}$ & $\begin{array}{l}\text { TC:HDL } \\
\text { (mmol/L) }\end{array}$ & $\begin{array}{l}\text { LDL:HDL } \\
\text { (mmol/L) }\end{array}$ \\
\hline AS Baseline & 0.834 & 0.65 & 0.37 & 0.17 & $\begin{array}{l}5.85 \pm \\
0.33\end{array}$ & $\begin{array}{l}1.27 \pm \\
0.12 \\
\end{array}$ & $\begin{array}{l}4.15 \pm \\
0.26\end{array}$ & 4.64 & 3.29 \\
\hline $\begin{array}{l}\text { AS } \\
\text { intervention }\end{array}$ & 0.843 & 0.59 & 0.35 & 0.07 & $\begin{array}{l}3.86 \pm \\
0.35\end{array}$ & $\begin{array}{l}1.39 \pm \\
0.06\end{array}$ & $\begin{array}{l}2.08 \pm \\
0.45 \\
\end{array}$ & 2.8 & 1.50 \\
\hline $\begin{array}{l}\text { AS post- } \\
\text { intervention }\end{array}$ & 0.84 & 0.65 & 0.38 & 0.17 & $\begin{array}{l}4.45 \pm \\
0.25\end{array}$ & $\begin{array}{l}1.37 \pm \\
0.10\end{array}$ & $\begin{array}{l}2.65 \pm \\
0.24\end{array}$ & 3.28 & 1.94 \\
\hline \multicolumn{10}{|c|}{ Two-year wash-out period } \\
\hline RS Baseline & 0.956 & 0.728 & 0.408 & 0.17 & $\begin{array}{l}4.71 \pm \\
0.56\end{array}$ & $\begin{array}{l}1.31 \pm \\
0.12 \\
\end{array}$ & $\begin{array}{l}2.90 \pm \\
0.69 \\
\end{array}$ & 3.62 & 2.25 \\
\hline $\begin{array}{l}\text { RS } \\
\text { intervention }\end{array}$ & 1.005 & 0.77 & 0.485 & 0.20 & $\begin{array}{l}3.60 \pm \\
0.31\end{array}$ & $\begin{array}{l}1.43 \pm \\
0.13\end{array}$ & $\begin{array}{l}1.91 \pm \\
0.34\end{array}$ & 2.65 & 1.35 \\
\hline $\begin{array}{l}\text { RS post- } \\
\text { intervention }\end{array}$ & 1.06 & 0.72 & 0.51 & 0.26 & $\begin{array}{l}4.95 \pm \\
0.0\end{array}$ & $1.22 \pm 0.0$ & $3.42 \pm 0.0$ & 4.1 & 2.80 \\
\hline
\end{tabular}

AS = atorvastatin; RS = rosuvastatin

Values expressed as means \pm SD

*given the fact that there were no significant differences in MP density during the intervention, only one post-intervention was taken

in non-users. Interestingly, however, when the analysis was confined to statin-users, longer-term statin use was related to reduced MP density. Given the fact that Experiment 2 used a case-control design instead of a longitudinal design, data on MP changes throughout each subject's statin regimen were unavailable. This result is, however, consistent with data from our case-study, in which MP density was assessed throughout the intervention. As shown in Figures 2 and 3, the case study participant showed a reduction in MP density in the more peripheral regions of

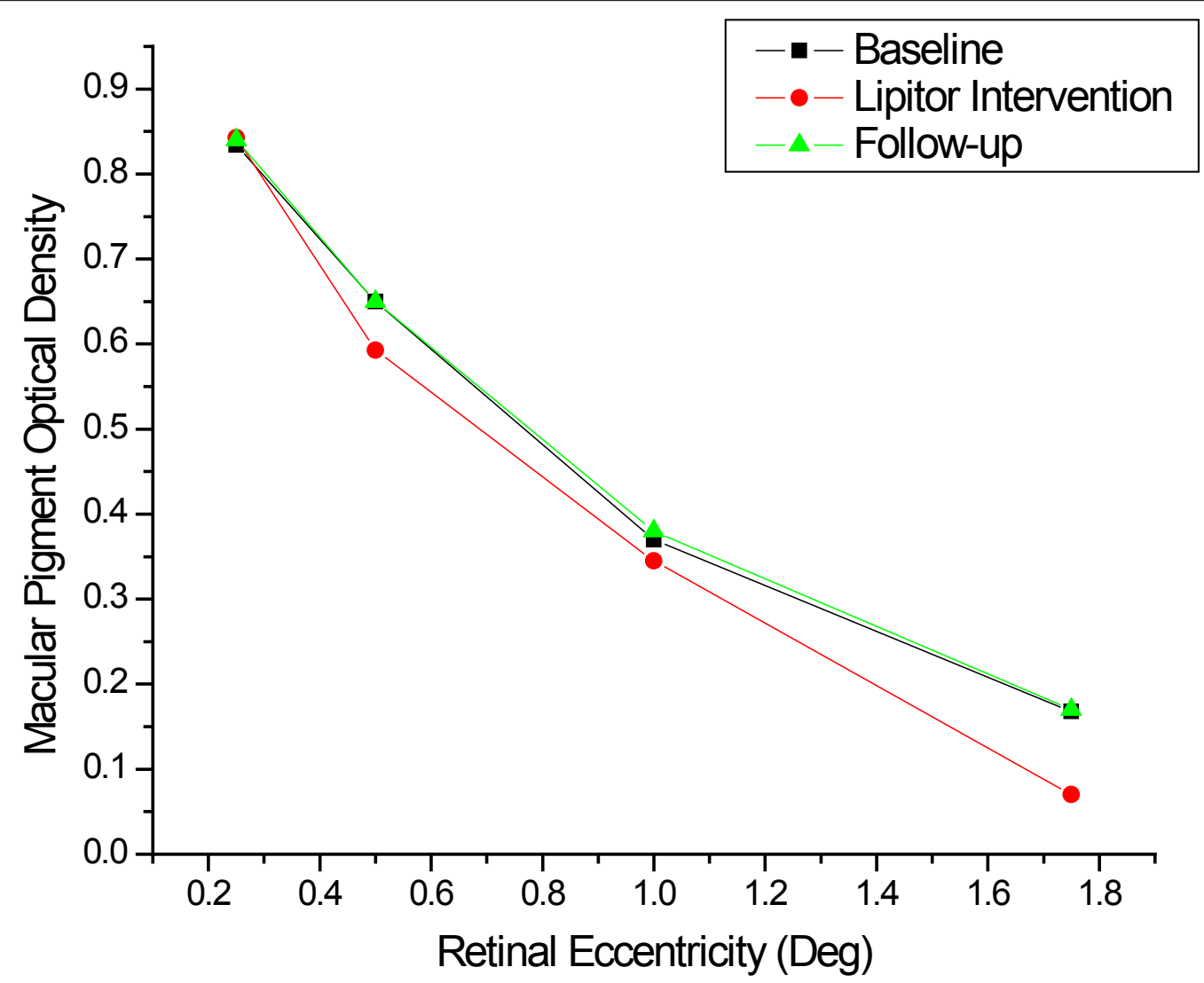

Figure 2 Spatial profile for MP density in one, well-practiced subject before, during and after intervention with $10 \mathrm{mg}$ atorvastatin 


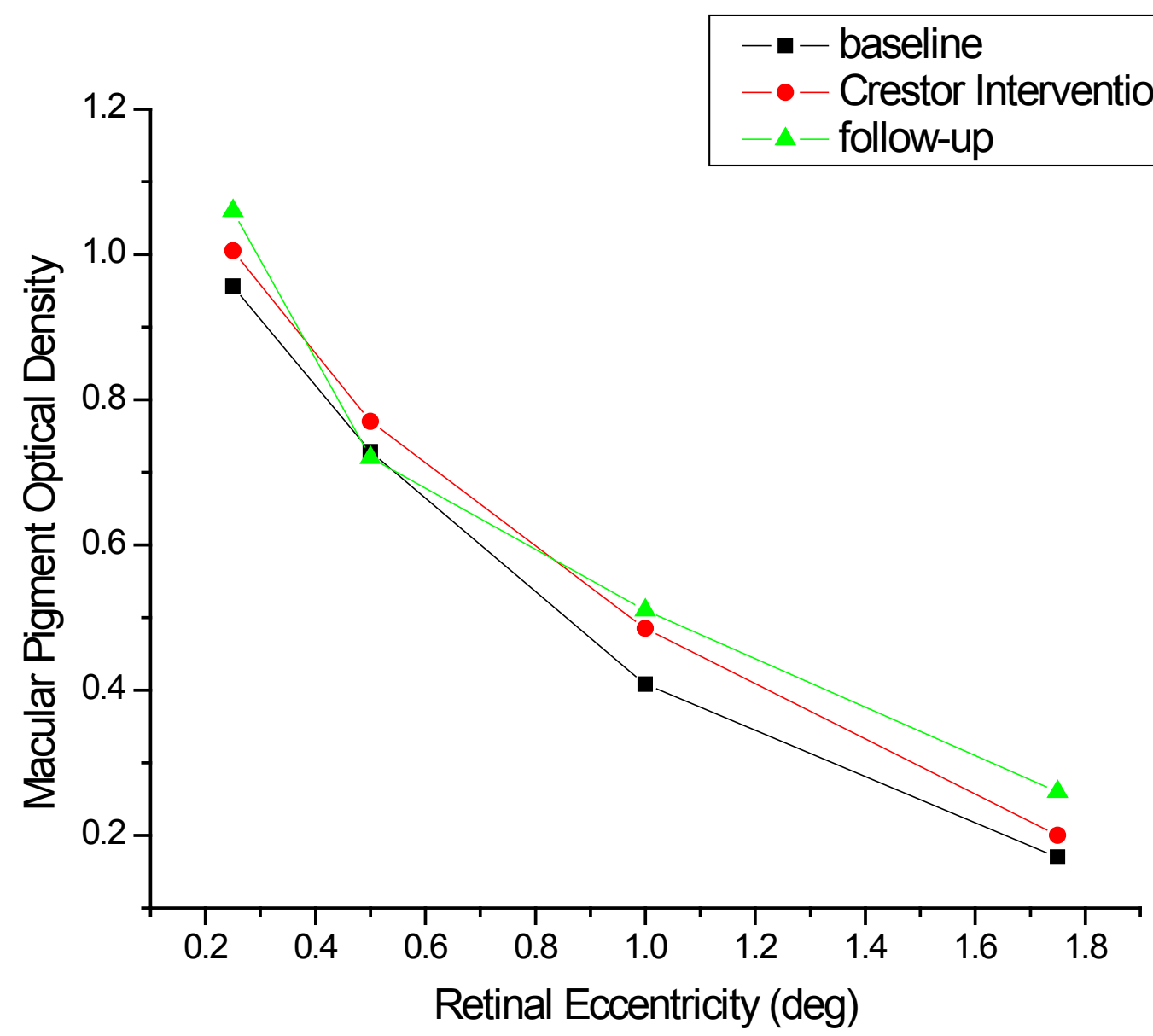

Figure 3 Spatial profile for MP density in one, well-practiced subject before, during and after intervention with 10 mg rosuvastatin

the retina that was only manifest during the intervention. This effect was only found for the lipophilic atorvastatin and not the hydrophilic rosuvastatin. Of course, the results from one subject are obviously only suggestive and whether the result would generalize is not known. Small effects were noticeable with this particular subject, however, because the subject was extremely well-practiced in the psychophysical task and did not change dietary habits from baseline to intervention within the rosuvastatin and atorvastatin conditions (which were separated by two years). These preliminary data suggest that more research is needed on the question of whether there are differences between rosuvastatin and atorvstatin on retinal health and whether long-term statin-use influences the retinal carotenoids. If stain use does lower MP density over time, it might be advisable to combine medication use with increased intake of carotenoid-rich foods or $\mathrm{L}$ and $\mathrm{Z}$ supplements. Vishwanathan et al [64] suggest that supplementation with egg yolk, for example, is capable of increasing MPOD in statin users with low MPOD at baseline.
The finding that gross concentrations of serum HDL and total cholesterol are related to MP is important. Poor lipid profiles and low MP levels may pose an increased risk for AMD (as well as other degenerative conditions) (e.g., $[16,17,31])$. Statins could reduce sclerotic processes within the eye that occur due to high cholesterol levels (e.g., thickening of sclera and Bruch's membrane) and reduce inflammatory processes. $\mathrm{L}$ and $\mathrm{Z}$ have also been shown to reduce inflammatory processes within the eye [e.g., Izumi-Nagi et al. [7]] and retard atherosclerosis (e. g., Dwyer et al., 2001 [57]). Managing intake of these compounds could help to aggregate their health effects as opposed to one partially offsetting the other.

\section{Acknowledgements}

The authors would like to thank DSM Nutritional Products and Kemin Health, L.C. for their generous financial support of this project. The authors would also like to acknowledge Laura Fletcher for coordinating the serum collection for Experiment 1.

\section{Author details}

'Human Biofactors Laboratory and Vision Sciences Laboratory, The University of Georgia, 601 Psychology Building, Athens, GA 30602-3013, USA. ${ }^{2}$ Vision 
Sciences Laboratory and Human Biofactors Laboratory, The University of Georgia, 520 Psychology Building, Athens, GA 30602-3013, USA. ${ }^{3}$ Vision Sciences Laboratory, The University of Georgia, 501 Psychology Building, Athens, GA 30602-3013, USA. "Kemin Health, L.C., 600 E. Court Ave, Suite A, DesMoines, IA 50309, USA.

Received: 14 November 2011 Accepted: 29 February 2012 Published: 29 February 2012

\section{References}

1. Maoka T: Recent progress in structural studies of carotenoids in animals and plants. Archives Biochem Biophys 2009, 483(2):191-195.

2. Demmig-Adams B, Gilmore AM, Adams WW 3rd: Carotenoids 3: in vivo function of carotenoids in higher plants. The FASEB J: Official Publ Federation Am Soc Exp Biol 1996, 10(4):403-412.

3. Vershinin A: Biological functions of carotenoids-diversity and evolution. Biofactors (Oxford, England) 1999, 10(2-3):99-104.

4. Namitha KK, Negi PS: Chemistry and biotechnology of carotenoids. Crit Rev Food Sci Nutr 2010, 50(8):728-760.

5. Chew BP, Park JS: Carotenoid action on the immune response. The J Nutr 2004, 134(1):257S-261S

6. Handelman GJ: The evolving role of carotenoids in human biochemistry. Nutr (Burbank, Los Angeles County, Calif) 2001, 17(10):818-822.

7. Izumi-Nagai K, Nagai N, Ohgami K, Satofuka S, Ozawa Y, Tsubota K, Umezawa K, Ohno S, Oike Y, Ishida S: Macular pigment lutein is antiinflammatory in preventing choroidal neovascularization. Arteriosclerosis, Thrombosis, Vasc Biol 2007, 27(12):2555-2562.

8. Krinsky Nl: Effects of carotenoids in cellular and animal systems. The Am J Clin Nutr 1991, 53(1 Suppl):238S-246S.

9. Krinsky Nl: Mechanism of action of biological antioxidants. Proc Soc Exp Biol Med Soc Expe Biol Med (New York, NY) 1992, 200(2):248-254.

10. Renzi LM, Hammond BR Jr: The relation between the macular carotenoids, lutein and zeaxanthin, and temporal vision. Ophthalmic \& Physiological Optics: The J British Coll Ophthalmic Opticians (Optometrists) 2010, 30(4):351-357.

11. Schmitz HH, Poor CL, Wellman RB, Erdman JW: Concentrations of selected carotenoids and vitamin A in human liver, kidney and lung tissue. J Nutr 1991, 121:1613-1621.

12. Yeum KJ, Shang FM, Schalch WM, Russell RM, Taylor A: Fat-soluble nutrient concentrations in different layers of human cataractous lens. Curr Eye Res 1999, 19(6):502-505.

13. Yeum KJ, Taylor A, Tang G, Russell RM: Measurement of carotenoids, retinoids, and tocopherols in human lenses. Invest Ophthalmol Vis Sci 1995, 36(13):2756-2761.

14. Bone RA, Landrum JT, Tarsis SL: Preliminary identification of the human macular pigment. Vision Res 1985, 25(11):1531-1535.

15. Bone RA, Landrum JT, Friedes LM, Gomez CM, Kilburn MD, Menendez E, Vidal I, Wang W: Distribution of lutein and zeaxanthin stereoisomers in the human retina. Exp Eye Res 1997, 64(2):211-218.

16. Bone RA, Landrum JT, Mayne ST, Gomez CM, Tibor SE, Twaroska EE: Macular pigment in donor eyes with and without AMD: a case-control study. Investigative Ophthalmol Vis Sci 2001, 42(1):235-240.

17. Beatty S, Murray IJ, Henson DB, Carden D, Koh H, Boulton ME: Macular pigment and risk for age-related macular degeneration in subjects from a Northern European population. Investigative Ophthalmol Vis Sci 2001, 42(2):439-446.

18. Falsini B, Piccardi M, larossi G, Fadda A, Merendino E, Valentini P: Influence of short-term antioxidant supplementation on macular function in agerelated maculopathy: a pilot study including electrophysiologic assessment. Ophthalmology 2003, 110(1):51-60.

19. Richer S, Stiles W, Statkute L, Pulido J, Frankowski J, Rudy D, Pei K, Tsipursky M, Nyland J: Double-masked, placebo-controlled, randomized trial of lutein and antioxidant supplementation in the intervention of atrophic age-related macular degeneration: the Veterans LAST study (Lutein Antioxidant Supplementation Trial). Optometry (St Louis, Mo) 2004, 75(4):216-230

20. Cangemi FE: TOZAL Study: an open case control study of an oral antioxidant and omega-3 supplement for dry AMD. BMC Ophthalmol 2007, 7:3-3.

21. Klaver CC, Ott A, Hofman A, Assink JJ, Breteler MM, de Jong PT: Is agerelated maculopathy associated with Alzheimer's Disease? The Rotterdam Study. Am J Epidemiol 1999, 150(9):963-968.
22. Johnson LV, Leitner WP, Rivest AJ, Staples MK, Radeke MJ, Anderson DH: The Alzheimer's A beta -peptide is deposited at sites of complement activation in pathologic deposits associated with aging and age-related macular degeneration. Proc Natl Acad Sci USA 2002, 99(18):11830-11835.

23. Dentchev T, Milam AH, Lee VMY, Trojanowski JQ, Dunaief JL: Amyloid-beta is found in drusen from some age-related macular degeneration retinas, but not in drusen from normal retinas. Mol Vis 2003, 9:184-190.

24. Delcourt C, Michel F, Colvez A, Lacroux A, Delage M, Vernet MH: Associations of cardiovascular disease and its risk factors with agerelated macular degeneration: the POLA study. Ophthalmic Epidemiol 2001, 8(4):237-249.

25. Hyman L, Schachat AP, He Q, Leske MC: Hypertension, cardiovascular disease, and age-related macular degeneration. Age-Related Macular Degeneration Risk Factors Study Group. Archives Ophthalmol 2000, 118(3):351-358.

26. Snow KK, Seddon JM: Do age-related macular degeneration and cardiovascular disease share common antecedents? Ophthalmic Epidemiol 1999, 6(2):125-143.

27. Tan JSL, Mitchell P, Smith W, Wang JJ: Cardiovascular risk factors and the long-term incidence of age-related macular degeneration: the Blue Mountains Eye Study. Ophthalmology 2007, 114(6):1143-1150.

28. Sun C, Klein R, Wong TY: Age-related macular degeneration and risk of coronary heart disease and stroke: the Cardiovascular Health Study. Ophthalmology 2009, 116(10):1913-1919.

29. Wong TY, Tikellis G, Sun C, Klein R, Couper DJ, Sharrett AR: Age-related macular degeneration and risk of coronary heart disease: the Atherosclerosis Risk in Communities Study. Ophthalmology 2007, 114(1):86-91.

30. Nowak M, Swietochowska E, Marek B, Szapska B, Wielkoszynski T, KosKudla B, Karpe J, Kajdaniuk D, Sieminska L, Glogowska-Szelag J, et al: Changes in lipid metabolism in women with age-related macular degeneration. Clin Exp Med 2005, 4(4):183-187.

31. Reynolds R, Rosner B, Seddon JM: Serum lipid biomarkers and hepatic lipase gene associations with age-related macular degeneration. Ophthalmology 2010, 117(10):1989-1995.

32. Sabbagh M, Zahiri HR, Ceimo J, Cooper K, Gaul W, Connor D, Sparks DL: Is there a characteristic lipid profile in Alzheimer's disease. J Alzheimer's Disease: JAD 2004, 6(6):585-589.

33. Cagnin A, Zambon A, Zarantonello G, Vianello D, Marchiori M, Mercurio D, Miccichè $F$, Ermani $M$, Leon $A$, Battistin L: Serum lipoprotein profile and APOE genotype in Alzheimer's disease. J Neural Transmission Supplementum 2007, 72:175-179.

34. Chakravarthy U, Wong TY, Fletcher A, Piault E, Evans C, Zlateva G, Buggage R, Pleil A, Mitchell P: Clinical risk factors for age-related macular degeneration: a systematic review and meta-analysis. BMC Ophthalmol 2010, 10:31-31.

35. Tomany SC, Wang JJ, Van Leeuwen R, Klein R, Mitchell P, Vingerling JR, Klein BEK, Smith W, De Jong PTVM: Risk factors for incident age-related macular degeneration: pooled findings from 3 continents. Ophthalmology 2004, 111(7):1280-1287.

36. Wang W, Shinto L, Connor WE, Quinn JF: Nutritional biomarkers in Alzheimer's disease: the association between carotenoids, $\mathrm{n}-3$ fatty acids, and dementia severity. J Alzheimer's Dis: JAD 2008, 13(1):31-38.

37. Rinaldi P, Polidori MC, Metastasio A, Mariani E, Mattioli P, Cherubini A, Catani M, Cecchetti R, Senin U, Mecocci P: Plasma antioxidants are similarly depleted in mild cognitive impairment and in Alzheimer's disease. Neurobiol Aging 2003, 24(7):915-919.

38. Lidebjer C, Leanderson P, Ernerudh J, Jonasson L: Low plasma levels of oxygenated carotenoids in patients with coronary artery disease. Nutr, Metab, Cardiovasc Dis: NMCD 2007, 17(6):448-456.

39. Moeller SM, Parekh N, Tinker L, Ritenbaugh C, Blodi B, Wallace RB, Mares JA: Associations between intermediate age-related macular degeneration and lutein and zeaxanthin in the Carotenoids in Age-related Eye Disease Study (CAREDS): ancillary study of the Women's Health Initiative. Archives Ophthalmol 2006, 124(8):1151-1162.

40. SanGiovanni JP, Chew EY, Clemons TE, Ferris FL, 3 rd, Gensler G, Lindblad AS, Milton RC, Seddon JM, Sperduto RD: The relationship of dietary carotenoid and vitamin A, E, and C intake with age-related macular degeneration in a case-control study: AREDS Report No. 22. Archives Ophthalmol 2007, 125(9):1225-1232. 
41. Tan JSL, Wang JJ, Flood V, Rochtchina E, Smith W, Mitchell P: Dietary antioxidants and the long-term incidence of age-related macular degeneration: the Blue Mountains Eye Study. Ophthalmology 2008, 115(2):334-341.

42. Michikawa T, Ishida S, Nishiwaki Y, Kikuchi Y, Tsuboi T, Hosoda K, Ishigami A, Iwasawa S, Nakano M, Takebayashi T: Serum antioxidants and age-related macular degeneration among older Japanese. Asia Pacific J Clin Nutr 2009, 18(1):1-7.

43. Parker RS: Absorption, metabolism, and transport of carotenoids. The FASEB J: Official Publ Federation Am Soc Exp Biol 1996, 10(5):542-551.

44. Goulinet S, Chapman MJ: Plasma LDL and HDL subspecies are heterogenous in particle content of tocopherols and oxygenated and hydrocarbon carotenoids. Relevance to oxidative resistance and atherogenesis. Arteriosclerosis, Thrombosis, Vasc Biol 1997, 17(4):786-796.

45. Wang W, Connor SL, Johnson EJ, Klein ML, Hughes S, Connor WE: Effect of dietary lutein and zeaxanthin on plasma carotenoids and their transport in lipoproteins in age-related macular degeneration. The Am J Clin Nutr 2007, 85(3):762-769.

46. Gross M, Yu X, Hannan P, Prouty C, Jacobs DR Jr: Lipid standardization of serum fat-soluble antioxidant concentrations: the YALTA study. The Am J Clin Nutr 2003, 77(2):458-466.

47. Wooten BR, Hammond BR Jr, Land RI, Snodderly DM: A practical method for measuring macular pigment optical density. Investigative Ophthalmol \& Vis Sci 1999, 40(11):2481-2489.

48. Vine AK, Stader J, Branham K, Musch DC, Swaroop A: Biomarkers of cardiovascular disease as risk factors for age-related macular degeneration. Ophthalmology 2005, 112(12):2076-2080

49. Broekmans WMR, Berendschot TTJM, Klöpping-Ketelaars IAA, de Vries AJ, Goldbohm RA, Tijburg LBM, Kardinaal AFM, van Poppel G: Macular pigment density in relation to serum and adipose tissue concentrations of lutein and serum concentrations of zeaxanthin. The Am J Clin Nutr 2002, 76(3):595-603.

50. Gruber M, Chappell R, Millen A, LaRowe T, Moeller SM, lannaccone A, Kritchevsky SB, Mares J: Correlates of serum lutein + zeaxanthin: findings from the Third National Health and Nutrition Examination Survey. The $J$ Nutr 2004, 134(9):2387-2394.

51. Third Report of the National Cholesterol Education Program (NCEP) Expert Panel on Detection, Evaluation, and Treatment of High Blood Cholesterol in Adults (Adult Treatment Panel III) final report. Circulation 2002, 106(25):3143-3421.

52. Hammond BR Jr, Wooten BR, Snodderly DM: Cigarette smoking and retinal carotenoids: implications for age-related macular degeneration. Vis Res 1996, 36(18):3003-3009.

53. Kirby ML, Beatty S, Loane E, Akkali MC, Connolly EE, Stack J, Nolan JM: A central dip in the macular pigment spatial profile is associated with age and smoking. Investigative Ophthalmol Vis Sci 2010, 51(12):6722-6728.

54. Loane E, Nolan JM, Beatty S: The respective relationships between lipoprotein profile, macular pigment optical density, and serum concentrations of lutein and zeaxanthin. Investigative Ophthalmol Vis Sci 2010, 51(11):5897-5905.

55. Saheki A, Terasaki T, Tamai I, Tsuji A: In vivo and in vitro blood-brain barrier transport of 3-hydroxy-3-methylglutaryl coenzyme A (HMG-CoA) reductase inhibitors. Pharmaceutical Res 1994, 11(2):305-311.

56. Panz VR, Raal FJ, Paiker J, Immelman R, Miles H: Performance of the CardioChek PA and Cholestech LDX point-of-care analysers compared to clinical diagnostic laboratory methods for the measurement of lipids. Cardiovasc J South Africa: Official J Southern Africa Cardiac Soc [And] South African Soc Cardiac Practitioners 2005, 16(2):112-117.

57. Santee J: Accuracy and precision of the Cholestech LDX System in monitoring blood lipid levels. Am J Health-System Pharmacy: AJHP: Official J The Am Soc Health-System Pharmacists 2002, 59(18):1774-1779.

58. Hartmann D, Thürmann PA, Spitzer V, Schalch W, Manner B, Cohn W: Plasma kinetics of zeaxanthin and 3'-dehydro-lutein after multiple oral doses of synthetic zeaxanthin. The Am J Clin Nutr 2004, 79(3):410-417.

59. Burke JD, Curran-Celentano J, Wenzel AJ: Diet and Serum carotenoid concentrations affect macular pigment optical density in adults 45 years and older. The J Nutr 2005, 135(5):1208-1214.

60. Stringham JM, Hammond BR, Nolan JM, Wooten BR, Mammen A, Smollon W, Snodderly DM: The utility of using customized heterochromatic flicker photometry (cHFP) to measure macular pigment in patients with age-related macular degeneration. Exp Eye Res 2008, 87(5):445-453.

61. Hammond BR Jr, Wooten BR, Smollon B: Assessment of the validity of in vivo methods of measuring human macular pigment optical density. Optometry Vis Sci: Official Publ Am Acad Optometry 2005, 82(5):387-404.

62. Thomson LR, Toyoda Y, Langner A, Delori FC, Garnett KM, et al: Elevated retinal zeaxanthin an prevention of light-induced photoreceptor cell death in quail. Investigative Ophthalmol Vis Sci 2002, 43(11):3538-3549.

63. Connor WE, Duell PB, Kean R, Wang Y: The prime role of HDL to transport lutein into the retina: evidence from HDL-deficient WHAM chicks having a mutant ABCA1 transporter. Investigative Ophthalmol Vis Sci 2007, 48(9):4226-4231.

64. Vishwanathan R, Goodrow-Kotyla EF, Wooten BR, Wilson TA, Nicolosi RJ: Consumption of 2 and 4 egg yolks/d for 5 wk increases macular pigment concentrations in older adults with low macular pigment taking cholesterol-lowering statins. The Am J Clin Nutr 2009, 90(5):1272-1279.

doi:10.1186/1476-511X-11-33

Cite this article as: Renzi et al:: The relation between serum lipids and lutein and zeaxanthin in the serum and retina: results from cross-sectional, case-control and case study designs. Lipids in Health and Disease 2012 11:33.

\section{Submit your next manuscript to BioMed Central and take full advantage of:}

- Convenient online submission

- Thorough peer review

- No space constraints or color figure charges

- Immediate publication on acceptance

- Inclusion in PubMed, CAS, Scopus and Google Scholar

- Research which is freely available for redistribution

Submit your manuscript at www.biomedcentral.com/submit
Biomed Central 